УДК 544.723

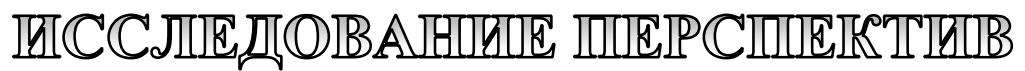

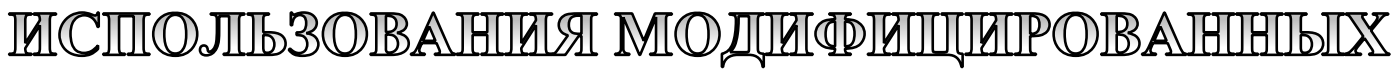

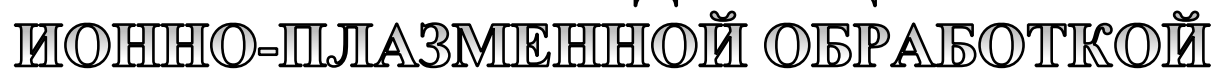

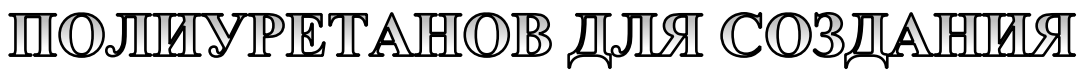

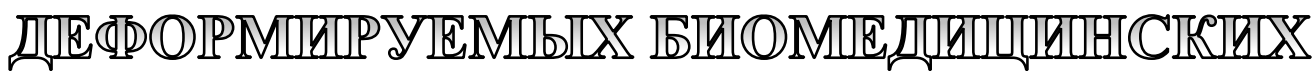

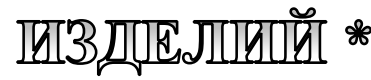

\author{
И.А. Морозов, Институт механики сплошных сред УрО РАН \\ А.С. Каменецких, Институт электрофизики УрО РАН \\ А.Ю. Беляев, Институт механики сплошных сред УрО РАН \\ М.Г. Щербань, Пермский государственный начиональный исследовательский университет \\ Л.М. Лемкина, Институт экологии и генетики микроорганизмов УрО РАН \\ Д.В. Ерошенко, Институт технической химии УрО РАН
}

\section{Для цитирования:}

Морозов И.А., Каменецких А.С., Беляев А.Ю., Щербань М.Г., Лемкина Л.М., Ерошенко Д.В. Исследование перспектив использования модифицированных ионно-плазменной обработкой полиуретанов для создания дефрормируемых биомедицинских изделий // Вестник Пермского федерального исследовательского центра. 2021. - № 4. - C. 19-30. https://doi.org/10.7242/2658-705X/2021.4.2

Плазменная обработка является перспективным методом модификации материалов. Однако деформация может привести к повреждению таких поверхностей. Упругие полиуретаны (модуль упругости до $30 \mathrm{MПа}$ ) обрабатывали иммерсионной плазменной имплантацией ионов азота с энергией ионов от 0,1 до 3 кэВ. Материалы исследовали методами атомно-силовой микроскопии, спектроскопией, измеряли смачиваемость и свободную энергию поверхности. Проводили механические одноосные испытания, после чего повторно исследовали поверхности. Исследовали сорбцию протеинов и бактерий, в том числе на поврежденных поверхностях.

В результате обработки с энергией ионов от 1 кэВ рельеф становится складчатым, существенно повышаются жесткость и смачиваемость поверхности; снижается адгезия как грамположительных (стафилококк), так и грамотрицательных (кишечная палочка) бактерий. Одноосная деформация ведет к образованию на обработанных поверхностях трещин. Такие изменения провоцируют рост бактерий до величин, превышающих их количество на необработанных материалах. Использование более низких энергий обработки (до 0,5 кэВ) привело к незначительному увеличению жесткости модифицированного слоя (в 1,5 ...2 раза по сравнению с необработанным материалом), что позволило избежать повреждения поверхности при

\footnotetext{
* Статья подготовлена при финансовой поддержке гранта РФФИ № 17-48-590057_p_a.
} 
растяжении. Благодаря увеличению свободной энергии поверхности обработанные материалы показали улучшенную сорбционную активность к протеину - альбумину; количество бактерий снизилось. Все изменения поверхности (влияние обработки, повреждения) имеют корреляцию как со свойствами исходного полимера, так и с режимом обработки.

Ключевые слова: ионно-плазменная деформация, протеины, бактерии.

\section{Введение}

Модификация поверхностей плазменной ионной имплантацией применяется для изменения тех или иных характеристик материалов. В зависимости от назначения увеличиваются их твердость, износостойкость, адгезионные и другие свойства. Перспективным направлениям является улучшение свойств полимерных медицинских изделий $[2,8,9]$ - катетеров, стентов, имплантатов и всего того, что находится в непосредственном контакте с живыми тканями. Плазменная обработка существенным образом изменяет физикохимические, механические свойства поверхности, а также шероховатость [10]. Особенностью плазменной обработки мягких материалов является формирование выраженной складчатой текстуры рельефа $[7,11]$. Эти изменения связаны с внутренними напряжениями, возникающими в модифицированном слое, жесткость которого превышает жесткость подложки [4].

Упругие полимеры незаменимы там, где требуются большие деформации. В частности, полиуретановые эластомеры используются в биомедицинских целях для изготовления грудных имплантов [1], межфаланговых протезов [3], катетеров [5]. Модификация этих изделий плазмой могла бы существенно улучшить их биомедицинские характеристики. Однако в этом случае преимушества покрытия оказываются не столь очевидными, так как внешняя деформация может привести к повреждению покрытия $[6,12]$.

В этой связи представляется актуальным исследование влияния внешней нагрузки на модифицированную поверхность полимера в зависимости от характера плазменной обработки, с оцен- обработка, полиуретан, поверхность,

кой ее воздействия на формирование и рост белковых и бактериальных пленок.

Проведенная работа носит экспериментальный характер. В ходе ее выполнения поверхность изготовленных полиуретанов была обработана плазменной имплантацией ионов азота; проведено механическое нагружение образцов, исследовано взаимодействие белков крови и бактериальных клеток с материалами до и после нагружения. На каждом этапе работы исследованы физические, биологические и структурномеханические особенности материалов на микро- и наноуровне.

Наши исследования установили связь между свойствами полимера, режимами модификации поверхности, нагрузкой и картиной повреждения поверхности, а также оценить влияние этих факторов на биомедицинские характеристики материалов.

\section{Материалы и методы}

Изготовление материалов. Исследовали две полиуретановые композиции (ПУ1 и ПУ2), изготовленные из преполимера и сшивающего агента согласно предписаниям поставщика в соотношении 100:34 (ПУ1, более твердый) и 100:46 (ПУ2, более мягкий). Преполимер: форполимер уретановый на основе простого полиэфира; сшивающий агент: отвердитель (МОКА) и пластификатор (полифурит). Компоненты вакуумировали и смешивали при температуре $80^{\circ} \mathrm{C}$. Смеси заливали в формы, оставляя верхнюю поверхность свободной, и отверждали в термошкафу (20 часов при температуре $\left.100^{\circ} \mathrm{C}\right)$. Толщина полученных пластин 2 мм, начальный модуль упругости 30 и $20 \mathrm{MПа,} \mathrm{разрывная} \mathrm{деформация} 800$ и $1000 \%$ для ПУ 1 и ПУ 2 соответственно. 
Плазменная обработка. Образцы обрабатывали плазменной иммерсионной имплантацией ионов азота. Для генерации плазмы в вакуумной камере применялся источник электронов с плазменным катодом на основе тлеющего разряда. Электроны ускорялись до энергии 10-20 эВ в области сетки плазменного катода. Электрически изолированный держатель образцов, охлаждаемый проточной водой, находился внутри вакуумной камеры на расстоянии 150 мм от сетки источника электронов. Образцы размещались внутри держателя и закрывались металлической сеткой с шагом между натянутыми нитями 10 мм. На держатель подавалось напряжение $U: 0,1,0,3,0,5,1,0$ или 3 кэВ. Ионы извлекались из плазмы и ускорялись в слое катодного падения потенциала вблизи поверхности сетки. Режимы обработки определялись из условия поддержания температуры образцов не выше $50^{\circ} \mathrm{C}$. Накопленная доза ионов составляла $10^{15}$ или $2 \times 10^{16}$ ион $/ \mathrm{cm}^{2}$.

Интерес представляет изучение обработанного слоя по толщине. Для этих целей были подготовлены поперечные срезы материалов - на поверхность обработанных материалов был нанесен слой (толщиной $\sim 1$ мм) полиуретана той же композиции, что и основа. С поперечной поверхности образца при помощи крио-ультрамикротома (Leica UC7) при температуре $-100^{\circ} \mathrm{C}$ была удалена часть материала. Срез на поверхности, содержащий сечение обработанной плазмой поверхности, изучали с помощью атомно-силовой микроскопии.

Механические испытания. Обработанные плазмой материалы подвергали одноосной циклической деформации на испытательной машине Testometric: 10 циклов нагрузки-разгрузки, максимальная деформация 50\%, скорость деформации 50\%/мин. Подобные деформации могут возникнуть уже в процессе технологических операций с изделием (транспортировка, монтаж).

Смачиваемость. Свободную энергию поверхности определяли методом
Оуэнса - Вендта - Рабеля - Каелбле на основе измерения краевых углов смачивания образцов тестовыми жидкостями (вода и диэтиленгликоль).

Образование биопленок. Необработанные и обработанные плазмой образцы, в том числе после механических испытаний, помещали в планшеты, в которые вносили стафилококк или кишечную палочку, содержащих $10 \times 7$ КоЕ/мл. Образцы термостатировали 48 часов при $37^{\circ} \mathrm{C}$, после чего отмывали в фосфатном буфере. В результате на поверхности образцов образуются занятые бактериями области толщиной в одну клетку (установлено методами атомно-силовой микроскопии). Исследовали как общее количество бактерий на поверхности, так и только жизнеспособные клетки. В первом случае анализ проводили при помощи оптической микроскопии. Количество жизнеспособных клеток определяли по уровню восстановления тетразолия MTS.

Адгезия белков крови. На полимеры наносили растворы человеческого сывороточного альбумина и фибронектина; инкубировали в течение 60 мин при $37^{\circ} \mathrm{C}$. Концентрацию белка в растворах определяли спектрофотометрически.

Микроскопия. Информация о микроструктуре поверхности была получена при помощи оптического 3D-видеомикроскопа (Hirox KH-7700), а также методами атомно-силовой микроскопии (ACM). В работе использовали АCM в полуконтактом режиме и в режиме наномеханического картирования. Первый режим применяли для получения представительных изображений рельефа $(15 \times 15$ мкм).

В режиме наномеханического картирования совместно с получением изображения происходит индентация поверхности с частотой $1 . .2$ кГц. В результате, каждой точке рельефа соответствует своя зависимость усилия $F(z)=k d$ от перемещения $z$ основания зонда, где $k$ и $d$ - жесткость и изгиб балки зонда. Данный режим использовали 
для исследования механических свойств поверхностей. Полученные усилия $F(z)$ обрабатывали при помощи модели Дерягина-Мюллера-Топорова.

Исследовали микроструктуру недеформированные образцов, прошедших механические испытания, а также в непосредственно деформированном состоянии. Для анализа рельефа со складчатой текстурой использовали Фурье-преобразование.

\section{Обсуждение результатов}

Результаты ионно-плазменной обработки с энергией $<1$ кэВ связаны со структурой исходного полимера и не показали существенных отличий для материалов различной жесткости (ПУ1 или ПУ2).

Жесткая фаза полиуретана на наноуровне имеет фибриллярную структуру и распределена в материале неоднородно: участки с низким модулем упругости чередуются с более жесткими (рис. 1,a). Плазменная обработка не приводит к значительным изменениям рельефа: фибриллярная структура частично разрушается, но, по-прежнему, различима на изображениях рельефа (рис. 1, б-г). Среднеквадратическая шероховатость изменялась незначительно (измеряли на областях $3 \times 3$ мкм): составила 1,6 нм для необработанной поверхности и возрастала до 2,0 нм для обработки 0,5 кэВ.
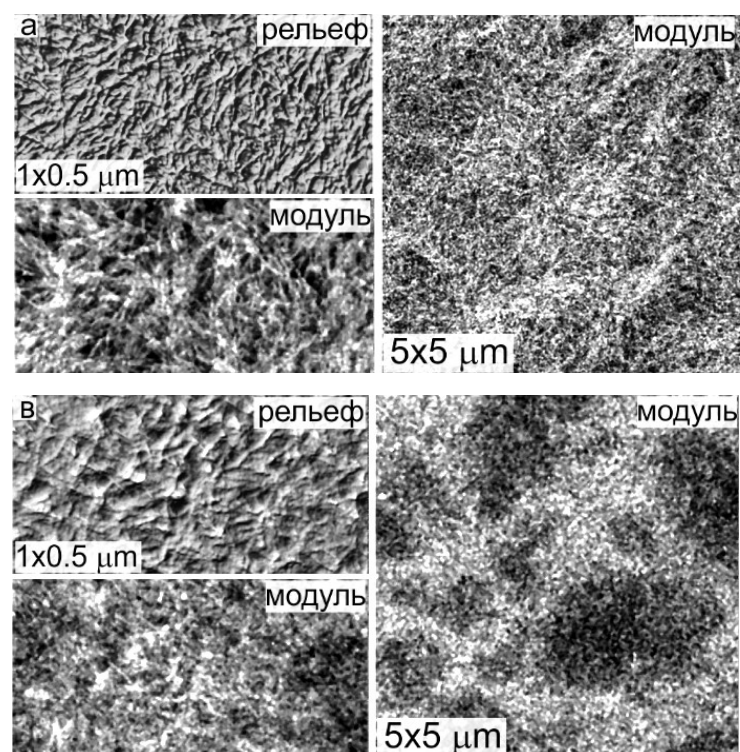

Существенные изменения происходят с модулем упругости поверхности: появляются области контрастной жесткости. Фибриллы жесткой фазы видны на изображениях рельефа, однако пропадают на соответствующих картах модуля. Следовательно, основные изменения материала, вызванные плазмой, происходят не на поверхности, а в некотором поверхностном слое: ионы влетают в поверхность на глубину до несколько нанометров (рис. 2,a), изменяя внутреннюю структуру и механические свойства полимера. Полученные результаты указывают на то, что внедрение ионов в жесткую фазу происходит на меньшую глубину и изменение ее свойств в процессе обработки происходит более интенсивно.

В результате обработки модуль возрастает в 1,5 (0,3 кэВ) .. 2,5 (0,5 кэВ) раза. После обработки 0,5 кэВ наблюдаются два пика (отмечены стрелками на рис. 2, б): свидетельство различного взаимодействия ионов азота с жесткой и мягкой фазами материала. Такое разделение заметно и после обработки 0,3 кэВ, однако, в этом случае материал становится даже мягче, чем при минимальной обработке 0,1 кэВ. Повидимому, это связано с особенностями формирования модифицированного слоя при малых энергиях обработки.

В результате обработки повышаются

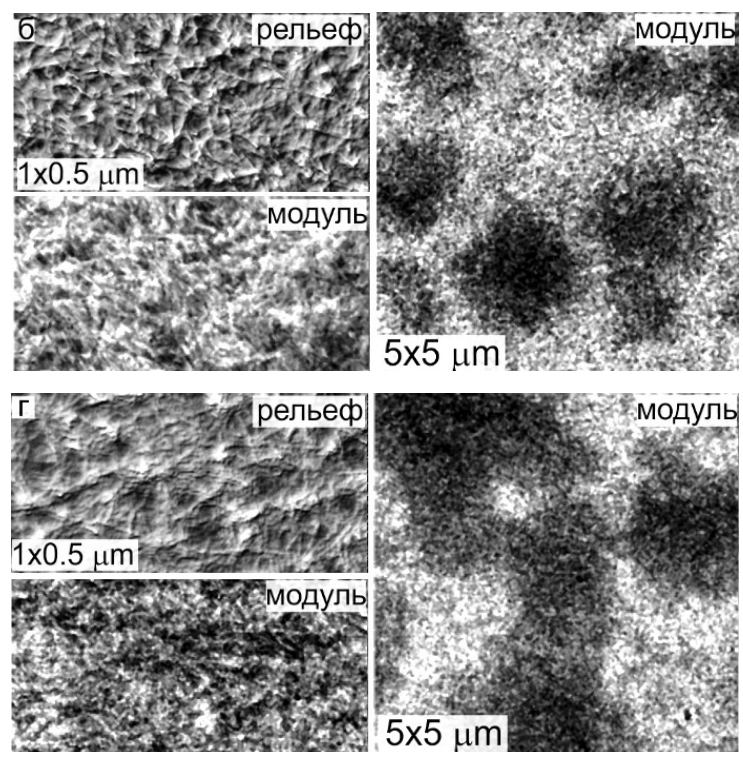

Рис. 1. Рельефы и карты модулей упругости необработанной (а) и обработанных поверхностей 0,1 кэВ (б), 0,3 кэВ (в) и 0,5 кэВ (г) на масштабе 1 мкм и 5 мкм 


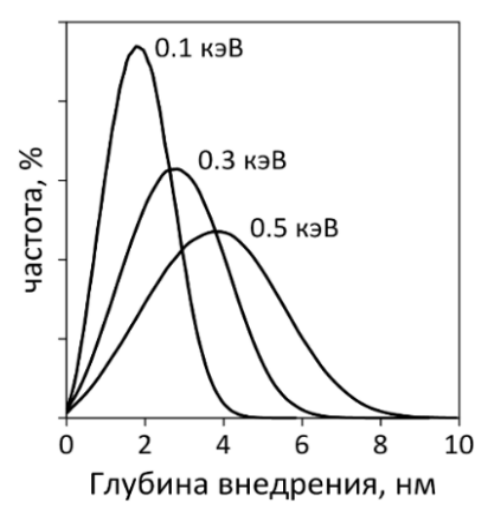

$a$

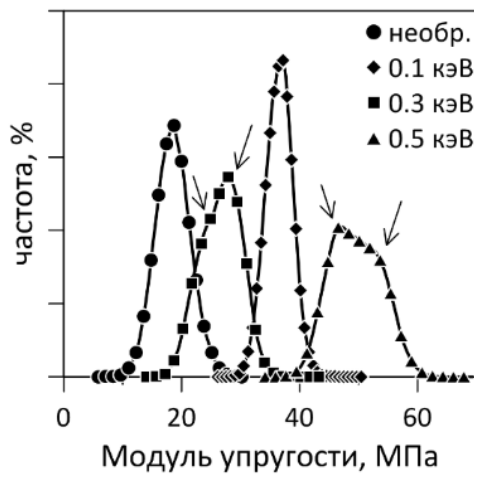

$\sigma$

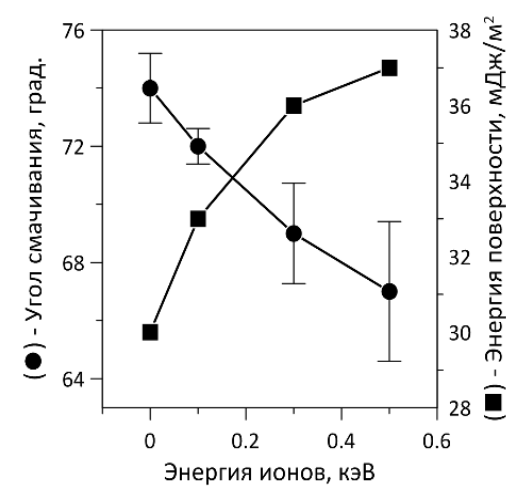

B

Рис. 2. Плотности распределения глубины внедрения ионов азота в полиуретан (a) и модуля упругости поверхностей (б); смачиваемость и энергия поверхности материалов (в).

Стрелками на (б) отмечено разделение распределения модуля на два пика

гидрофильность и энергия поверхности (рис. 2, в). Отметим, что более интенсивная обработка с энергией 1 и 3 кэВ не приводит к существенному изменению как контактного угла смачивания, так и энергии поверхности (после обработки 3 кэВ энергия поверхности данного материала составляла 38 мДж/ $\left.\mathrm{m}^{2}\right)$.

Адсорбция альбумина на разных поверхностях исследована в литературе довольно широко. На эту величину оказывают смешанное влияние гидрофобность, энергия поверхности, шероховатость, наличие электростатического заряда. В нашем случае (рис. 3, $a$ ) увеличение альбумина объясняется преимущественно возросшей смачиваемостью и энергией поверхностей: на более гидрофильных поверхностях поглощение белка обусловлено притяжением неполярных частей молекул альбумина к поверхности.

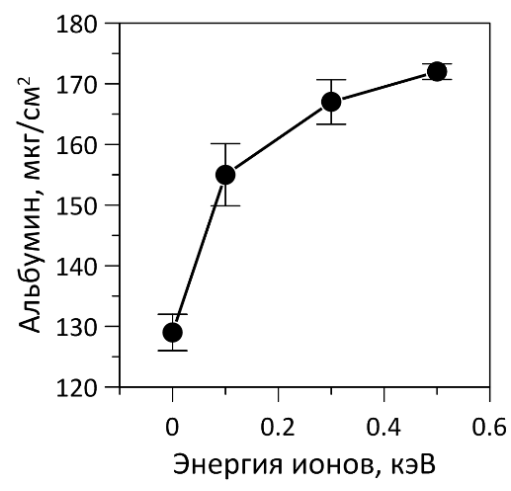

$a$
Анализ АСМ-изображений рельефов поверхностей с нанесенным альбумином до и после плазменной обработки (рис. 3, б-в) позволил заключить следующее: на поверхности необработанного полиуретана с нанесенным (высушенным) альбумином видны неоднородно распределенные островки на аналогичной обработанной поверхности однородная ячеистая структура. Это указывает на то, что поверхность необработанного полиуретана на наноуровне имеет неоднородную активность по отношению к альбумину. Этими неоднородностями являются участки жесткой и мягкой фазы. Плазменная обработка приводит к выравниванию свойств поверхности, и пленка (высохшего) альбумина становится более однородной. Обработанные плазмой поверхности показали хорошие антибактериальные
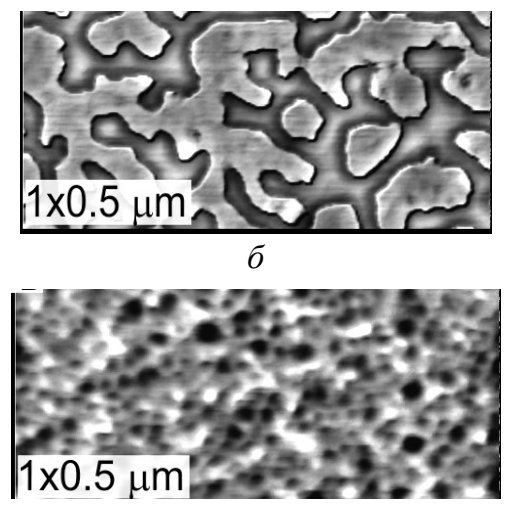

B

Рис. 3. Количество сорбировавщегося альбумина (а) и АСМ-изображения рельефа поверхности необработанного (б) и обработанного 0,5 кэВ (в) полиуретана с белковым слоем 
свойства. Количество жизнеспособных болезнетворных бактерий кишечной палочки на обработанных поверхностях уменьшается почти в три раза (рис. 4). Шероховатость и текстура рельефа оказывают существенное влияние на адгезию бактерий. Однако в нашем случае рельеф не имеет выраженных особенностей и снижение жизнеспособных бактерий можно объяснить с точки зрения энергии поверхности: свободные радикалы вызывают окислительный стресс, что ведет к гибели клеток.

Исследование материалов в растянутом состоянии показало устойчивость поверхностей к удлинениям не менее $50 \%$. Обработанные участки жесткой и мягкой фазы вытягиваются вдоль оси деформация, образуя на поверхности ориентированные области. Повреждения покрытия при этом не происходит (рис. 5).

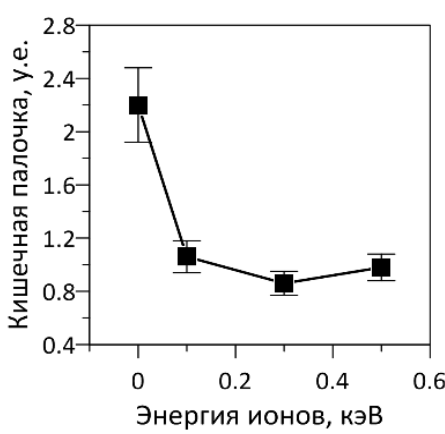

$a$
В результате ионно-плазменной обработки при энергии обработки 1 кэВ и более на поверхности полимеров формируется структура складок (рис. 6).

Установлено, что поверхность полиуретана после ионно-плазменной обработки $\geq 1$ кэВ характеризуется спектром складок различной длины волны от 200 до 1000 нм. Структура волн преимущественно зависит только от энергии обработки - для одной энергии, но разной дозы обработки пары значений амплитуда-длина волны практически совпадают. При обработке 1 кэВ складки имеют одну амплитуду в широком диапазоне длин волн. Видна определенная связь между структурой волн и исходным полимером. Для более жесткого материала ПУ1 по сравнению с ПУ2 значения смещаются в область малых длин волн и амплитуд. Для более мягкого полиуретана плазменная обработка вызвала более сильные измене-

Рис. 4. Количество жизнеспособных бактерий кишечной палочки (a); оптические и АСМизображения колоний кишечной палочки на необработанной (б) и обработанной 0,5 кэВ (8) поверхностях. На необработанной поверхности контуры кишечной палочки четкие, виднь начинающие делиться бактерии; на обработанной поверхности бактерии не имеют четкой формь (рис. 4, в): их клеточная стенка начала разрушаться на стадии инкубаџии

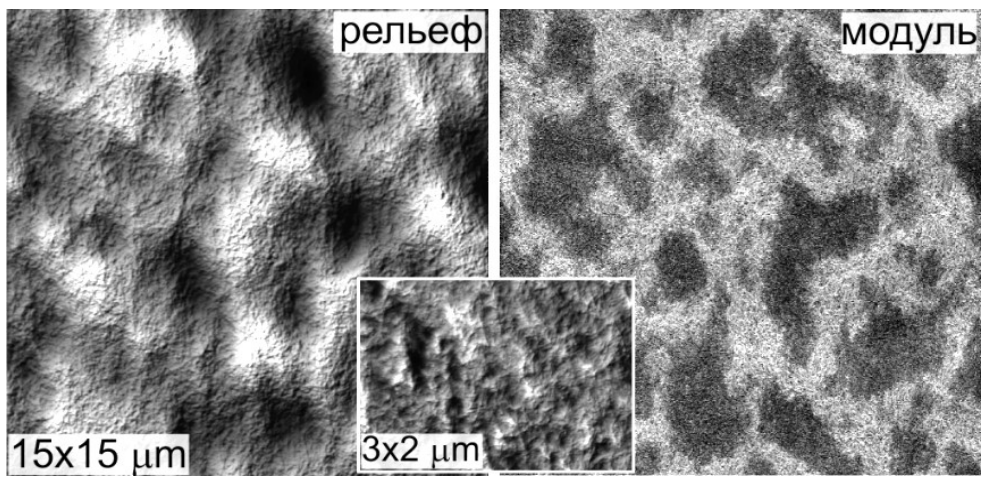

Рис. 5. АСМ-изображения рельефа и модуля упругости поверхности растянутого на 50\% обработанного (0,5 кэВ) полиуретана. Вставкой показан увеличенный участок рельефа. 


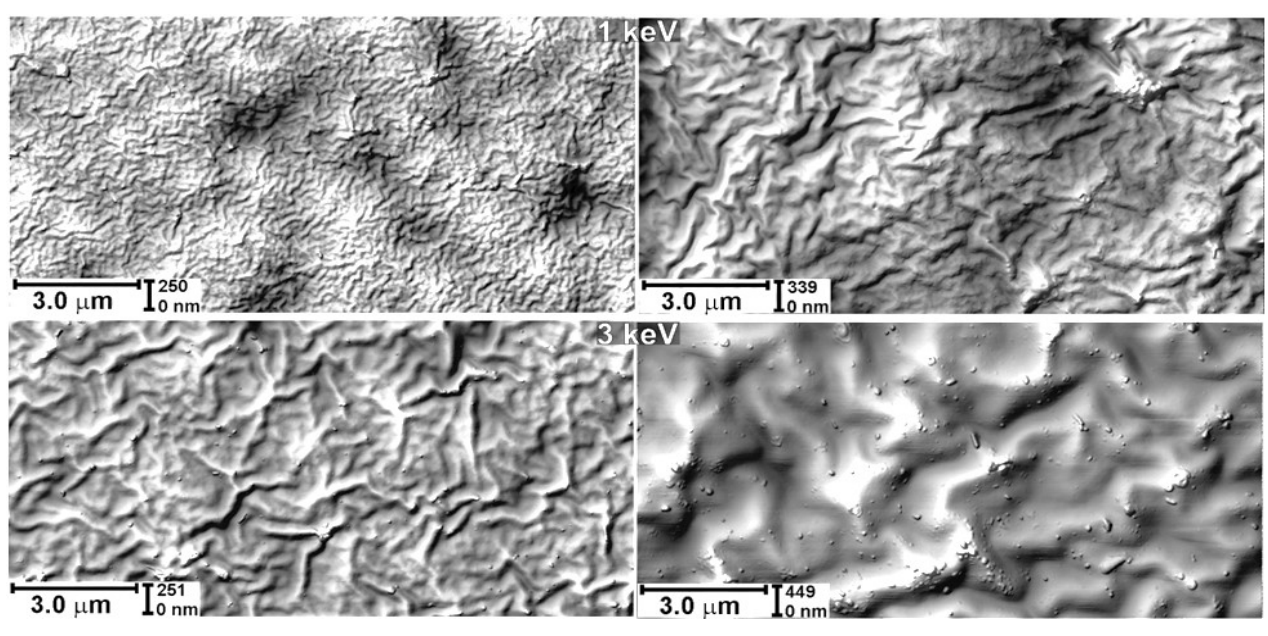

$a$

6

Рис. 6. Поверхности материалов ПУ1 (а) и ПУ2(б) после ионно-плазменной обработки 1 или 3 кэВ

ния рельефа: появился целый спектр складок амплитудой $2 \ldots 3$ нм и длинами волн $800 \ldots 1800$ нм. Влияние на рельеф увеличения энергии обработки с 1 до 3 кэВ зависит от свойств подложки: для материала ПУ1 это отразилось в трех- и четырехкратном увеличении шероховатости. Шероховатость ПУ2 увеличилась в два раза (на поверхности появилась выраженная структура складок).

Жесткость обработанных поверхностей (энергия обработки 1 кэВ и более) в целом однородна. В зависимости от вида обработки жесткость поверхности изменяется от 40 до 800 МПа (материал ПУ2) и от 300 до 1400 МПа (материал ПУ1). Очевидно, что данная величина зависит как от свойств (распределение жесткости по толщине) обработанного слоя, так и от находящейся под ним полимерной «подложки». Исследование обработанных поверхностей по толщине (поперечные срезы материалов с нанесенным сверху слоем полимера), показало, что обработанный слой четко выступает на карте рельефа АСМ-изображения, а также имеет контраст на картах механических свойств: малую глубину индентации, малую силу адгезии зонд-материал и высокую жесткость. Результаты показали, что толщина слоя составила от 11 , 31, 44 нм (материал ПУ1) и 11, 23, 41 нм (ПУ2) для энергии обработки 0,5, 1 и 3 кэВ соответственно.
Исследование колоний клеток стафилококка, выращенных на изучаемых материалах, показало снижение до 5 раз количества жизнеспособных клеток по сравнению с необработанным полиуретаном. Результаты имеют корреляцию как со структурой поверхности (шероховатость, фрактальные свойства и доля складок), так и с энергией поверхности (рис. 7). Угол смачивания с увеличением энергии обработки изменяется слабо, поэтому основным фактором, первоначально снизившим количество жизнеспособных клеток, является изменение энергии. Дальнейшее снижение клеток можно объяснить с точки зрения развития складчатой структуры. Еще одним объяснением является образование на материале жестких бугорков, дополнительно препятствующих закреплению бактерий на поверхности.

В абсолютных цифрах, стафилококка адсорбируется значительно меньше, чем кишечной палочки. Это связано с различием в гидрофобности их клеточной стенки и поверхностном заряде. Количество клеток стафилококков на поверхности связано в первую очередь со смачиваемостью поверхности и на исследуемых поверхностях существенно не изменяется. Однако мы наблюдали незначительное снижение адгезии бактерий стафилококка на материале ПУ2 при увеличении угла смачивания. 


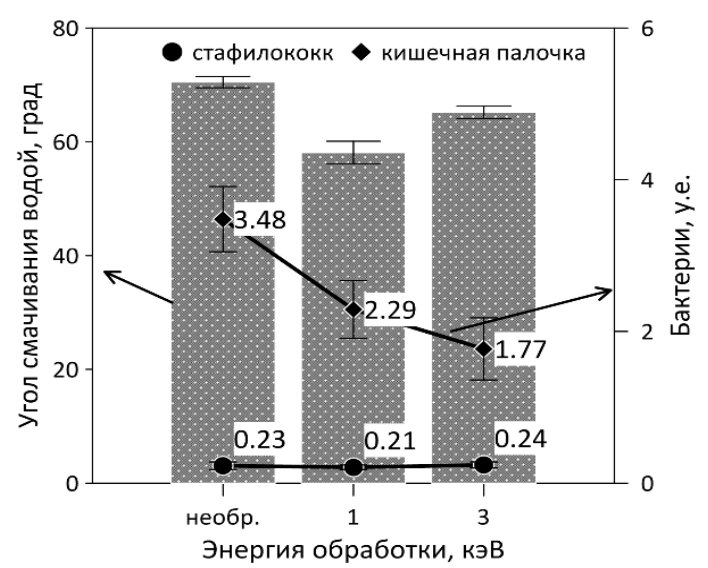

$a$

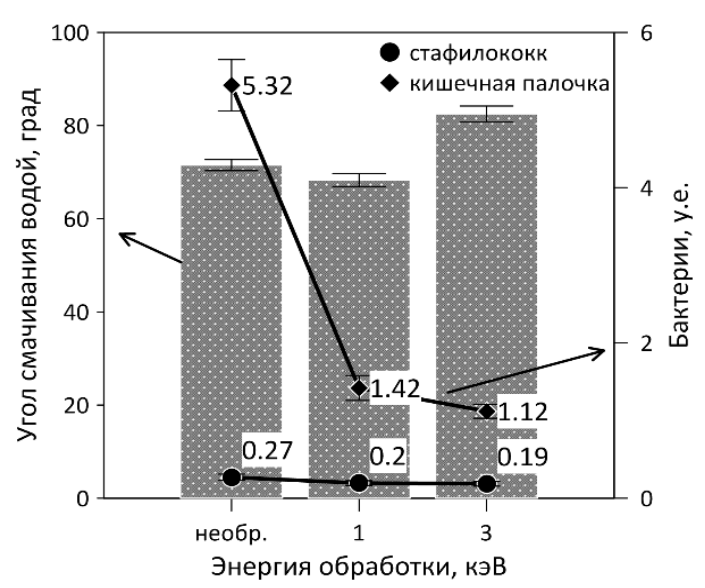

$\sigma$

Рис. 7. Смачиваемость и антибактериальные свойства необработанных и обработанных поверхностей ПУ1 (а) и ПУ2 (б)

Клетки бактерий кишечной палочки более чувствительны к химическому составу подложки: так, на необработанном ПУ2 интенсивность дыхания этих биопленок была в 1,5 раза больше, чем на ПУ1. После обработки полиуретана количество бактерий резко убывает. Так как угол смачивания существенно не меняется, то в первую очередь это связано со структурными особенностями рельефа: возникшая после обработки складчатая поверхность ПУ2 с длиной волны от 1000 до 1500 нм, затрудняет колонизацию и оказывает дополнительный антибактериальный эффект на КП.

Результаты исследования адгезии белков крови (альбумина и фибронектина) показало, что количество сорбированного белка на поверхностях необработанных полимеров было примерно равным, как в случае альбумина, так и фибронектина. Обработка 0,5 кэВ приводила к увеличению сорбции альбумина и снижению сорбции фибронектина. Количество сорбированного белка как в случае альбумина, так и фибронектина на ПУ1 после обработки 1 кэВ было значительно выше, чем на необработанном полимере. Обработка вида 3 кэВ полимеров вызывала увеличение количества связанного альбумина, однако практически не влияла на сорбцию фибронектина.
В результате механической нагрузки на обработанных поверхностях образуются трещины и складки, сонаправленные с осью деформации (рис. 8). После снятия нагрузки под влиянием остаточных деформаций края трещин оказываются раскрытыми и на поверхности остаются складки результат сжатия материала в поперечном направлении. Ширина поперечных трещин составила $250 \ldots 400 \mathrm{Hм;} \mathrm{средняя} \mathrm{глубина}$ совпадает с оценочной толщиной поверхностного слоя: 25 или 45 нм.

Нагрузка вызвала увеличение среднеквадратичной шероховатости поверхностей (за исключением ПУ1-3кэВ, где шероховатость незначительно уменьшилась) на величину $20 \ldots 30$ нм.

Исследование роста биопленок на поврежденных поверхностях показало, что бактерии локализуются в местах дефектов покрытия (рис. 9). Удельная площадь биопленки, по сравнению с неповрежденным покрытием, возрастает, во-первых, за счет увеличения площади контакта между бактерией и покрытием. Другим фактором, увеличивающим бактериальную адгезию, является открытая в трещинах поверхность необработанного полимера.

Известно, что шероховатость и текстура рельефа существенным образом влияют на способность бактерий закрепляться на поверхности. В нашем случае на увеличение кишечной палочки на деформирован- 


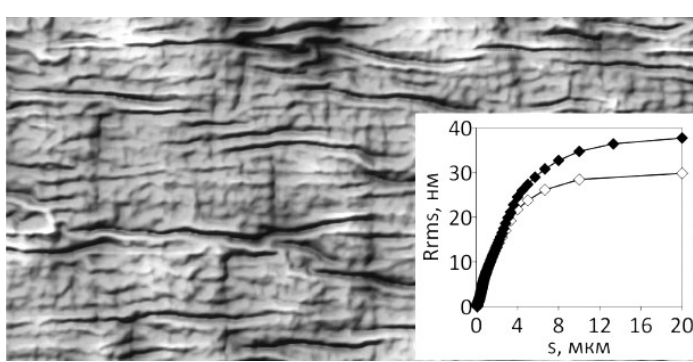

$a$

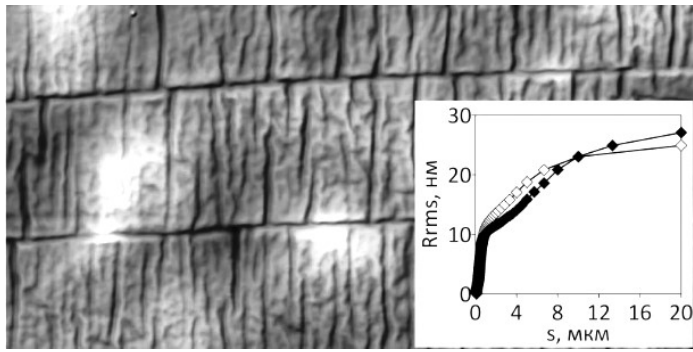

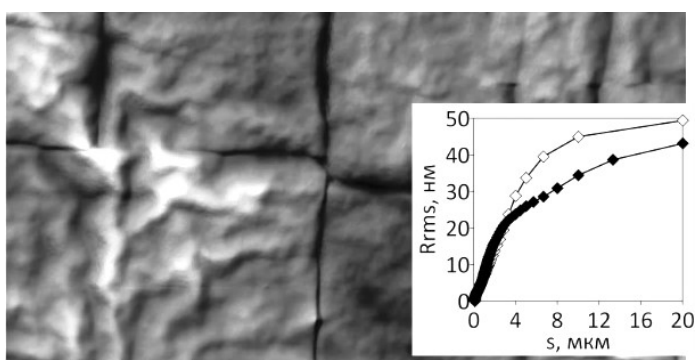

$\sigma$

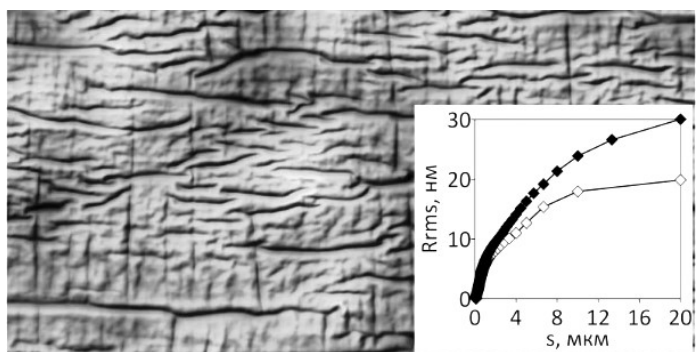

2

Рис. 8. Изображения $(20 \times 10$ мкм) обработанных поверхностей после нагрузки: а, б - ПУ1: 1 и 3 кэВ; в, г-ПУ2: 1 и 3 кэВ. Вставками показаны шероховатости до (৩) и после (•) нагружения

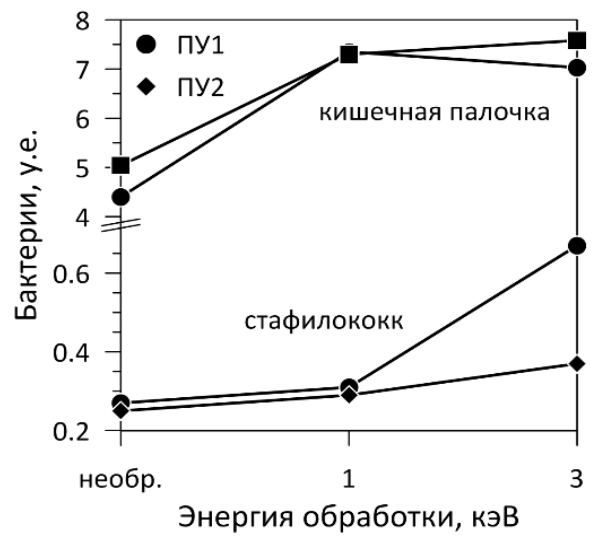

$a$

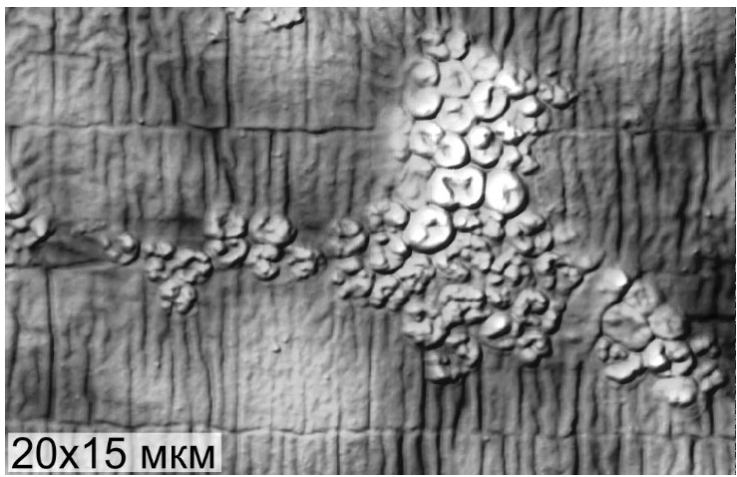

6

Рис. 9. Влияние нагружения на адгезию бактерий: количество жизнеспособных бактерий на обработанных поверхностях после деформаџии (а) и (б) - кишечная палочка на материале ПУУ 2 (1 кэВ)

ных поверхностях в первую очередь повлияли протяженные длинные трещины: количество этих бактерий возрастает в 1,5 раза после приложения нагрузки и существенно не зависит от подложки. Двукратный рост стафилококка, зафиксированный на материале ПУ1 при 3 кэВ, связан с разглаживанием поверхности после нагрузки. Представляется, что несмотря на широко представленный в литературе положительный эффект от подобных покрытий, реальная эксплуатация таких материалов может привести к негативным последствиям как для самого изделия, так и для окружающих тканей организма.

\section{Заключение}

Исследовали влияние плазменной иммерсионной имплантации ионов азота (энергия ионов от 0,1 до 3 кэВ) на биомедицинские свойства эластичных полиуретанов различной жесткости.

В результате обработки с энергией ионов азота 1 кэВ и выше рельеф полимера приобретает складчатую структуру. Образовавшиеся складки поверхности характеризуются спектром длин волн и амплитуд и особенно выражены на более мягком материале. Изменения поверхности существенным образом повлияли на адгезию бактерий кишечной палочки, чья 
сорбционная активность на обработанных поверхностях снизилась в 2 раза и более. В первую очередь это связано с появлением текстуры разветвленных складок, а также с увеличением шероховатости рельефа. Незначительно уменьшилась и адгезия стафилококка; на это повлияло как увеличение гидрофобности, так и особенности рельефа поверхности.

Однако циклическая одноосная деформация вызвала необратимые изменения плазменного покрытия: на поверхностях появились поперечные трещины и сонаправленные с осью нагружения складки. Это привело к существенному увеличению, по сравнению с необработанным материалом, бактериальной адгезии как кишечной палочки, так и стафилококка. Основным фактором роста бактерий явились протяженные дефекты рельефа - трещины и складки. Таким образом, вызванные деформацией изменения структуры покрытия нивелируют первоначальный положительный антибактериальный эффект плазменной обработки. Учитывая также то, что при многоцикловых нагрузках трещины прорастают вглубь материала, разрушая мягкую подложку, использование таких материалов в реальных изделиях недопустимо.

С другой стороны, низкоэнергетическая обработка (энергия ионов азота $0,1 \ldots 0,5$ кэВ) поверхности упругого полиуретана не оказала значительного влияния на структурно-механические свойства материала. Ионы внедряются в материал на глубину до нескольких нанометров, и значительные структурно-механические изменения материала происходят не на поверхности (структура поверхности практически не изменилась), а в поверхностном нанослое. В связи с двухфазной структурой полимера, данный слой имеет неоднородную жесткость: участки с относительно высоким и низким модулями упругости, соответствующие модифицированным областям жесткой и мягкой фазы. Такая обработка привела к повышению гидрофобности и свободной энергии поверхности полиуретана. Это положительным образом отразилось на биомедицинских характеристиках образцов: была достигнута улучшенная сорбция протеинов (альбумин, связано с гидрофобностью и энергией поверхности) и снижена жизнеспособность кишечной палочки (косвенно объясняется возросшей энергией поверхности и обусловлено появлением на поверхности свободных радикалов, вызвавших окислительный стресс бактерий).

Проведенная плазменная обработка вызвала увеличение модуля упругости поверхности по сравнению с необработанным полимером в $1,5 \ldots 2$ раза. По сравнению с более высокой интенсивностью обработки (1 кэВ и более), данные покрытия показали устойчивость к механическим нагрузкам при растяжении не менее $50 \%$. Материалы с малой энергией обработки имеют перспективы дальнейшего всестороннего исследования с целью разработки деформируемых биомедицинских изделий с улучшенными свойствами.

\section{Библиографический список}

1. Осоргина И.В., Порозова С.Е., Плаксин С.А., Морозов И.А. Влияние длительной экспозиции в организме на состояние полиуретановых оболочек маммапротезов // Медицинская техника. 2016. - № 1. - C. 45-49.

2. Alves P., Pinto S., de Sousa H.C., Gil M.H. Surface modification of a thermoplastic polyurethane by low-pressure plasma treatment to improve hydrophilicity // Journal of Applied Polymer Science. 2011. - Vol. 122. - № 4. - P. 2302-2308.

3. Beliaev A., Svistkov A., Iziumov R., Osorgina I., Kondyurin A., Bilek M., McKenzie D. Modelling of the mechanical behavior of a polyurethane finger interphalangeal joint endoprosthesis after surface modification by ion implantation // IOP Conf. Series: Materials Science and Engineering. - 2016. Vol. 123. - Article ID 012001.

4. Cammarata R.C., Trimble T.M., Srolovitz D.J. Surface stress model for intrinsic stresses in thin films // Journal of Materials Research. - 2000. - Vol. 15. - № 11. - P. 2468-2474. 
5. Kondyurina I., Nechitailo G.S., Svistkov A.L., Kondyurin A., Bilek M. Urinary catheter with polyurethane coating modified by ion implantation // Nuclear Instruments and Methods in Physics Research B. - 2015. - Vol. 342. - P. 39-46.

6. Morozov I.A., Mamaev A.S., Bannikov M.V., Beliaev A.Yu., Osorgina I.V. The Fracture of PlasmaTreated Polyurethane Surface under Fatigue Loading // Coatings. - 2018. - Vol. 8. - № 2. - P. 75-1-11.

7. Morozov I.A., Mamaev A.S., Osorgina I.V., Beliaev A.Y., Izumov R.I., Oschepkova T.E. Soft polyurethanes treated by plasma immersion ion implantation: structural-mechanical properties of surface modified layer // Journal of Applied Polymer Science. - 2018. - Vol. 135. - № 11. - P. 45983.

8. Morozov I.A., Mamaev A.S., Osorgina I.V., Lemkina L.M., Korobov V.P., Belyaev A.Yu., Porozova S.E., Sherban M.G. Structural-mechanical and antibacterial properties of a soft elastic polyurethane surface after plasma immersion N2+ implantation // Materials Science \& Engineering C. - 2016. - Vol. 62. - P. 242-248.

9. Panchuk D.A., Sadakbaeva Z.K., Bagrov D.V., Kechek'yan A.S., Bol'shakova A.V., Abramchuk S.S., Yarysheva L.M., Volynskii A.L., Bakeev N.F. Specific features of surface structuring during deformation of plasma-treated polymer films // Polymer Science Series A. - 2010. - Vol. 52. - № 8. - P. 794-800.

10. Stüber M., Niederberger L., Danneil F., Leiste H., Ulrich S., Welle A., Marin M., Fischer H. Surface Topography, Surface Energy and Wettability of Magnetron-Sputtered Amorphous Carbon (a-C) Films and Their Relevance for Platelet Adhesion // Advanced Engineering Materials. 2007. - Vol. 9. - № 12. - P. 1114-1122.

11. Tsougeni K., Tserepi A., Boulousis G., Constantoudis V., Gogolides E. Control of Nanotexture and Wetting Properties of Polydimethylsiloxane from Very Hydrophobic to Super-Hydrophobic by Plasma Processing // Plasma Processes and Polymers. - 2007. - Vol. 4. - № 4. - P. 398-405.

12. Volynskii A.L., Panchuk D.A., Sadakbaeva Z.K., Bol'shakova A.V., Kechek'yan A.S., Yarysheva L.M., Bakeev N.F. Formation of a regular microrelief in deformation of plasma-treated polymer films // Doklady Physical Chemistry. - 2009. - Vol. 427. - № 2. - P. 133-135.

\title{
THE PROSPECTS OF USING ION-PLASMA MODIFICATION OF POLYURETHANES FOR CREATING DEFORMABLE BIOMEDICAL PRODUCTS
}

\author{
I.A. Morozov ${ }^{1}$, A.S. Kamenetskikh ${ }^{3}$, A.Y. Beliaev ${ }^{1}$, M.G. Scherban ${ }^{2}$, \\ L.M. Lemkina ${ }^{4}$, D.V. Eroshenko \\ ${ }^{I}$ Institute of Continuous Media Mechanics UB RAS \\ ${ }^{2}$ Perm State National Research University \\ ${ }^{3}$ Institute of Electrophysics UB RAS \\ ${ }^{4}$ Institute of Ecology and Genetics of Microorganisms UB RAS \\ ${ }^{5}$ Institute of Technical Chemistry UB RAS
}

\section{For citation:}

Morozov I.A., Kamenetskikh A.S., Beliaev A.Y., Scherban M.G., Lemkina L.M., Eroshenko D.V. The prospects of using ion-plasma modification of polyurethanes for creating deformable biomedical products // Perm Federal Research Center Journal. - 2021. - № 4. - P. 19-30. https://doi.org/10.7242/2658-705X/2021.4.2

Plasma treatment is a promising method for modifying materials. However, deformation of the elastic substrate can damage the modified layer that can lead to various undesirable consequences. Elastic polyurethanes (elastic modulus up to $30 \mathrm{MPa}$ ) were studied; the polymers were treated by plasma immersion ion implantation of nitrogen ions with energy from 0,1 to $3 \mathrm{keV}$. Materials were investigated by atomic force microscopy, spectroscopy, the wettability and free energy of the surface were measured. Mechanical uniaxial tests were carried out and then surfaces were re-examined. Proteins and bacteria adsorption was studied, including the damaged surfaces under mechanical loads. As a result of the treatment with ion energy from $1 \mathrm{keV}$, the relief gets folded, the stiffness and hydrophobicity of the surface significantly increases, the adhesion of both gram-positive (staphylococcus) and gram-negative (Escherichia coli) bacteria decreases. Cyclic uniaxial deformation causes transverse cracks and longitudinal folds on treated surfaces. Such changes provoke the bacterial growth to values greater than their number on untreated materials. The lower plasma energies (up to $0,5 \mathrm{keV}$ ) resulted in a slight increase in the stiffness of the modified layer (by 1,5 ... 2 times 
compared to untreated material), which made it possible to avoid surface damage under stretching. Due to the increased hydrophobicity and surface energy, the treated materials showed improved protein adsorption, the number of bacteria has decreased. All the surface changes (treatment, damage) correlate both with the properties of the original substrate (polyurethane is a block copolymer) and with the treatment mode.

Keywords: ion plasma treatment, polyurethane, surface, deformation, proteins, bacteria .

\section{Сведения об авторах}

Морозов Илья Александрович, кандидат физико-математических наук, старший научный сотрудник, Институт механики сплошных сред УрО РАН - филиал Пермского федерального исследовательского центра УрО РАН («ИМСС УрО РАН»), 614013, г. Пермь, ул. Академика Королева, 1; e-mail: ilya.morozov@gmail.com

Каменеиких Александр Сергеевич, кандидат физико-математических наук, старший научный сотрудник, Институт электрофизики УрО РАН (ИЭФ УрО РАН), 620016, г. Екатеринбург, ул. Амундсена 106; e-mail: alx@iep.uran.ru

Беляев Антон Юрьевич, младший научный сотрудник, «ИМСС УрО РАН»; e-mail: belyaev@icmm.ru Щербань Марина Григорьевна, кандидат химических наук, доцент, Пермский государственный национальный исследовательский университет (ПГНИУ), 614990, г. Пермь, ул. Букирева, 15; e-mail: ma-sher74@mail.ru

Лемкина Лариса Марковна, кандидат медицинских наук, научный сотрудник, Институт экологии и генетики микроорганизмов УрО РАН («ИЭГМ УрО РАН»), 614000, г. Пермь, ул. Голева, 13; e-mail:1.lemkina@iegm.ru

Ерошенко Дарья Владимировна, кандидат биологических наук, научный сотрудник, Институт технической химии УрО РАН («ИТХ УрО РАН»), 614013, г. Пермь, ул. Академика Королева 3; e-mail: dasha.eroshenko@gmail.com 